\title{
The international statistical congress (1853-1876): Knowledge transfers and their limits
}

Citation for published version (APA):

Randeraad, N. (2011). The international statistical congress (1853-1876): Knowledge transfers and their limits. European History Quarterly, 41(1), 50-65. https://doi.org/10.1177/0265691410385759

Document status and date:

Published: 01/01/2011

DOI:

10.1177/0265691410385759

Document Version:

Publisher's PDF, also known as Version of record

Document license:

Taverne

Please check the document version of this publication:

- A submitted manuscript is the version of the article upon submission and before peer-review. There can be important differences between the submitted version and the official published version of record.

People interested in the research are advised to contact the author for the final version of the publication, or visit the DOI to the publisher's website.

- The final author version and the galley proof are versions of the publication after peer review.

- The final published version features the final layout of the paper including the volume, issue and page numbers.

Link to publication

\footnotetext{
General rights rights.

- You may freely distribute the URL identifying the publication in the public portal. please follow below link for the End User Agreement:

www.umlib.nl/taverne-license

Take down policy

If you believe that this document breaches copyright please contact us at:

repository@maastrichtuniversity.nl

providing details and we will investigate your claim.
}

Copyright and moral rights for the publications made accessible in the public portal are retained by the authors and/or other copyright owners and it is a condition of accessing publications that users recognise and abide by the legal requirements associated with these

- Users may download and print one copy of any publication from the public portal for the purpose of private study or research.

- You may not further distribute the material or use it for any profit-making activity or commercial gain

If the publication is distributed under the terms of Article $25 \mathrm{fa}$ of the Dutch Copyright Act, indicated by the "Taverne" license above, 
The International Statistical

Congress ( I 853-I 876):

Knowledge Transfers and their Limits

(C) The Author(s) 2011

Reprints and permissions: sagepub.co.uk/journalsPermissions.nav DOI: $10.1|77 / 026569| 4 \mid 0385759$ ehq.sagepub.com

(SAGE

\title{
Nico Randeraad
}

Maastricht University, the Netherlands

\begin{abstract}
Between 1853 and I876 nine international statistical congresses were held in different European cities. The aim of the congresses was to bring about uniformity in the themes and methods of national statistics. However, this goal could not be attained overnight. Much of the failure to bring about rapid change was due to the difficulties in realizing effective knowledge transfers, that is, effective communication, in an age that was not quite ready for truly international activities. It has been shown that the second half of the nineteenth century was a period of numerous experiments in internationalism, but at the same time rampant nationalism nipped many initiatives in the bud. Increasing nationalism, however, is not the only explanation for the collapse of the international statistical congress. The implicit faith in the possibility of a neutral science of statistics also created huge difficulties. Realizing statistical uniformity presupposed that the underlying facts and figures were comparable. This uniformity was far removed from the rapidly changing administrative reality in nineteenth-century Europe.
\end{abstract}

\section{Keywords}

Congresses, statistics, transfer history

\section{Introduction}

Between 1853 and 1876 nine international statistical congresses were held in different European capitals. ${ }^{1}$ The aim of the congresses was to bring about uniformity in the themes and methods of national statistics. Altogether, the nine congresses brought together more than 5000 participants, mostly from European countries but, particularly towards the end, also from the Americas, Northern Africa and Turkey. ${ }^{2}$ The congress was a real hub of knowledge, with a huge transfer potential.

\section{Corresponding author:}

Nico Randeraad, Maastricht University, the Netherlands

Email: n.randeraad@maastrichtuniversity.nl 
It would be overly simplistic to assume that the international statistical congresses were a straightforward success. To begin with, no more congresses were held after 1876, though the participants still harboured hopes of continuation. More importantly, by then it was clear that the aspirations of the early congresses had been too high. International uniformity in statistics was evidently not a goal that could be reached overnight. Much of this failure to bring about rapid change can be explained by the difficulties in realizing effective knowledge transfers, in other words effective communication, in an age that was not fully prepared for truly international activities. It has been shown that the second half of the nineteenth century was a period of numerous experiments in internationalism, but at the same time rampant nationalism nipped many initiatives in the bud. ${ }^{3}$ French and German statisticians and political economists, for example, were continually quarrelling about population figures. The French were anxious to prove that the size of their population was not dangerously decreasing, whereas the Germans proudly presented statistical laws demonstrating their nation's vigour, which manifested itself in rapid population growth. ${ }^{4}$ Increasing nationalism, however, is not the only explanation for the collapse of the international statistical congress. The implicit faith in the possibility of a neutral science also created huge difficulties. Realizing statistical uniformity presupposed a comparability of the underlying facts and numbers that was far removed from the rapidly changing administrative reality in nineteenth-century Europe. Moreover, despite the communication revolution of the nineteenth century, the ability of governments and other actors to share knowledge advances in the field of statistics was limited. By highlighting different stages of (attempted) knowledge transfer by means of the international statistical congress, I hope to demonstrate that close cooperation and uniformity were anything but self-evident.

\section{Transfers and Exchanges}

The study of transfers and exchanges is currently very much in vogue. In many ways, this is a sign of the times. Today's buzz words, such as globalization, mobility, networks and hubs, typically refer to connections and interchanges in a $24 / 7$ world. Nothing is fixed anymore, panta rhei. This situation is reflected in historiography too. Rigidly national histories are becoming scarce. Interest in comparative history (comparing two or more distinct cases, often at the level of nation-states) seems to have faded and been replaced by 'relational' perspectives. Whether this approach is entirely novel is open to dispute. It could be argued that many historians of art, music and literature, but also of science and technology, have long employed what has recently been proposed as a new approach in political and cultural history. Arguments about the novelty of the approach aside, there are many areas in which transnational perspectives can produce new insights. ${ }^{5}$

'Transfer' is understood here as the migration of information, expertise and knowledge from one environment to another, whereas 'exchange' plainly refers to the act of giving something (i.e. elements of knowledge) in return for something 
received. ${ }^{6}$ Michel Espagne has made good use of the concept of cultural transfer, in particular in the framework of Franco-German relations. ${ }^{7}$ Other historians have opened up the study of transfers and connections to extra-European contexts, introducing related concepts such as connected, shared and entangled history. ${ }^{8}$ A promising new avenue in historical methodology has been opened up by Michael Werner and Bénédicte Zimmermann, who coined the expression 'histoire croisée' to resolve the apparent contradiction between comparative and transfer history. ${ }^{9}$

To some extent, the aforementioned approaches of comparison and transfer go hand in hand, particularly when applied to geographically close regions where there are existing political and economic relationships. As Donald Sassoon inadvertently showed, the history of socialism in Western Europe is at once a history of comparable political parties, a history of cultural transfer and a history of multiple crossroads in the development of a political concept. ${ }^{10}$ Similarly, but more explicitly joining the discussion on knowledge transfer, Pierre-Yves Saunier assembled a series of contributions on the linkages binding together municipalities, often geographically far apart, in their quest to improve local government. ${ }^{11}$ In a similar vein, I edited a volume on the spread of administrative knowledge of cities since the early modern period. ${ }^{12}$ Following the same line, Wolfram Kaiser's analysis of the spread of free trade in the decade after the Great Exhibition (1851) can be read as an accumulation of various transnational approaches. ${ }^{13}$ Curiously enough, there is often an inherently optimistic undercurrent in the transfer literature. It is as if the discovery of the transfer channel is proof of its functionality. This article adopts a more critical approach by focusing on the adaptation, selection and disruption of knowledge during transfer processes. The migration of knowledge is no less conflict-ridden than the migration of people.

Hartmut Kaelble, a renowned comparativist, recently joined the discussion surrounding the checks and balances of transnational approaches. He views 'histoire croiséé as a combination of comparative and transfer history. According to Kaelble, histoire croisée goes beyond the predominantly bilateral design of both comparative and transfer studies but at the same time is critical of portraying transnational milieus as if they have a life of their own. Instead, it focuses upon constantly changing perspectives on the phenomena under investigation as they move from one context to another. He also notes that the number of case studies is still rather small, and that we should not forget to carry out empirical research before embarking on theoretical discussions. Methodologically, he continues, it is necessary to be precise in one's use of concepts. Would it not be better, he asks (perhaps rhetorically), to start from a kind of hierarchy in approaches stemming from transnationality, transfer history and entangled history? ${ }^{14}$

There is a danger in many of the relational approaches sketched out above of concentrating solely on the mechanics of exchange and the channels of transfer, thereby losing sight of the content of the knowledge transferred and the effectiveness of knowledge dissemination. Transfer cannot be detached completely from content and results. I would therefore like to focus on one area of knowledge 
(statistics), and on the political, cultural and institutional factors that fostered or impeded knowledge transfer in this area. Following Kaelble's line of reasoning, I aim to disentangle a typically 'entangled' topic, that is, the burgeoning international scientific congresses of the second half of the nineteenth century, paying particular attention to the international statistical congress.

Transfer and exchange are essentially forms of communication. Communication, in short, is the process of exchanging information. Basic communication theory distinguishes between three stages of communication: encoding; transmitting; and decoding messages. In other words, a message is drawn up, sent and received. All three stages impact on the content of the message, and disturb the communication. Moreover, the communication process rarely stops after one message, but is followed, traversed and thwarted by numerous other exchanges, creating a complex web of information streams. In order to analyse this web, one does not have to start from an advanced state of data flows. It suffices to begin at an elementary level. The consequences for the understanding of a more complex web are then easy to grasp.

I will attempt to apply the model of a simple communication process to the international statistical congresses. ${ }^{15}$ In the three sections that follow I will discuss: (1) the sources of statistical knowledge (encoding); (2) the transfer arena (transmitting); and (3) the reception and further use of transnational knowledge (decoding and re-encoding).

\section{The Sources of Statistical Knowledge}

The first stage of communication involves preparing the message. Statistics seemed to have a distinct advantage in this respect. In the course of the first half of the nineteenth century most European states had established some sort of national statistical service. The institutional form of the statistical services differed from state to state, but there was a common, albeit rudimentary, understanding of the use of statistics for measuring the economic and social potential of the nation. ${ }^{16}$ During the first World's Fair, the Great Exhibition of London which was held in 1851, the Belgian astronomer and statistician Adolphe Quetelet, supported by his countryman Auguste Visschers and a small circle of experts from various countries in Europe, developed the idea of an international congress on statistics. Due to Napoleon III's coup in December 1851 and international troubles concerning Schleswig-Holstein in 1852, the first congress was eventually held in September 1853, in Brussels.

This was not Quetelet's first scientific conference, or even his first international congress. Nevertheless, in the early 1850 s the phenomenon of international congresses was relatively new. It is debatable whether its predecessors, such as the Deutsche Naturforscher Versammlung (since 1822), the British Association for the Advancement of Science (since 1831) and the Congressi degli Scienziati Italiani (since 1839), were national or international gatherings. ${ }^{17}$ Strictly speaking, some of them brought together representatives from different states, but it has been convincingly shown that their primary purpose was to further the national cause by 
consolidating a national science. ${ }^{18}$ In any case, Quetelet had been a guest at more than one, and not just as an observer. During one of his visits to London (in 1834) he helped to establish the Statistical Society. Moreover, immediately before the international statistical congress he organized a meteorological congress, also in Brussels. Quetelet saw a direct link between the two. The statistical congress, he said, aimed at studying 'in another context, the fluctuations, movements and obstacles in modern societies'. ${ }^{19}$ Other international congresses held in those years addressed specific threats to bourgeois society. Notably, the first sanitary congress, held in Paris in 1851, was convened to address the danger of cholera epidemics, and the first congress on demography and public hygiene was held in Brussels in $1852 .^{20}$

It is safe to say that the statistical congresses forged links between the various international scientific initiatives of the early 1850s, mainly because statistics was a broad and fluctuating concept and much more than the auxiliary science it is today. To a certain extent it was equated with 'good administration', a connotation it had acquired in the Revolutionary-Napoleonic period around 1800. Around the midcentury statistics embodied the hope of discovering the 'laws of society' and improving the moral and material standard of living. Quetelet's work, in particular his Sur l'homme et le développement des ses facultés, ou Essai de physique sociale (Brussels 1835), had encouraged this widespread conviction. In this book he introduced the idea of the 'average man'. He believed that measuring a person's moral and physical abilities would show large or small deviations from the arithmetic mean. According to Quetelet, the fluctuations around the mean followed general laws. Physical and mental qualities, such as height and girth, but also the predisposition towards crime, could be classified along the Gaussian curve. These tantalizing ideas had already been travelling around Europe and America well before the congress was first organized. The predictable pattern of all systematic observations greatly contributed to the belief that human society could be controlled and managed. It is not surprising, therefore, that the most popular objects of statistical study were directly or indirectly connected to social reform. ${ }^{21}$ Crime, poverty, disease, prostitution and - more generally - issues related to the composition and development of the population were favourite topics, but they certainly did not exhaust the possibilities. Everything that could be counted was a potential target for the statisticians of the nineteenth century. Hence, among the topics discussed during the congresses we encounter cities, lighthouses, wine, fisheries, works of art, books, Esperanto, cultural institutions, the Red Cross and many more.

The indistinct boundaries of statistics were an ambivalent factor in the development of the international congresses. On the one hand, they attracted many participants, on average more than 500 at each gathering, all with a different interest in the matter; on the other hand, this sometimes led to a Babel-like confusion surrounding the purpose of the congresses. In 1869, at the seventh congress, not for the first time, the inner circle of those present discussed the true nature of statistics. The Dutch representative Simon Vissering proposed making a clear distinction between the historical school and the mathematical school, implying that the first had become somewhat obsolete. The Belgian, Xavier Heuschling, strongly 
opposed this notion, and gave preference to the historical school, which he identified with the activities of statesmen and officials, that is with public administration, whereas he assigned the mathematical school to the austere world of academia. His maître Quetelet immediately intervened by stating clearly that he did not want to hear about divisions, and that science and administration were interdependent. Another authoritative statistician, the German, Ernst Engel, head of the Prussian statistical office, agreed with Quetelet, and noted that he had assembled 180 definitions of statistics from textbooks and periodicals. ${ }^{22}$ He argued that it was unnecessary and undesirable to make a priori choices.

It is quite remarkable that at the seventh congress there was still no real consensus about what its subject matter essentially was. Admittedly, statistics was not very different from other disciplines in this respect. The boundaries of scientific disciplines were elastic. Scientific congresses could be dedicated to a whole range of interests, such as 'demography and public hygiene', or 'geographical, cosmographical and commercial sciences'. The same supporters of social reform could be found at different congresses. Marie Matthieu von Baumhauer, head of the Dutch bureau of statistics, for example, had been active in the movement for prison reform, and had attended its first international conference held in Frankfurt in $1846 .{ }^{23}$ Moreover, successive congresses hardly ever followed the requirements of a specific science at a particular moment in time. ${ }^{24}$

Who, then, determined the agenda of a specific session? In the case of the statistical congresses, the next venue was decided during the last plenary session of each congress, whereas the organizing country was responsible for setting the agenda. This procedure was maintained throughout the period that the international statistical congresses were held. The first congress, held in Brussels, was organized by a subcommission of the Belgian Central Commission of Statistics, chaired by Quetelet, who had taken the initiative to convene the meeting. Usually, the preparatory commissions consulted the heads of the national statistical bureaus or similar bodies, and other prominent statisticians who had regularly participated in earlier meetings. Some topics recurred at each conference, such as population statistics (in particular the censuses) and the organization of statistics at national and international level. However, the organizing countries invariably added specific themes to the agenda. The Belgian commission, for example, probably following the express wish of Auguste Visschers, wanted to pay particular attention to the statistics of workers' budgets. Visschers was a member of the Belgian Mining Council, had been active in the first investigations into women and child labour, and was fairly familiar with the burgeoning interest in this topic in Britain. He had already discussed the question of working-class housing at the Congress on Public Hygiene held in 1851-52. In his proposal to the statistical congress he explicitly referred to the work of Joseph Fletcher for the Statistical Society of London. Due to its obvious political nature this topic was dropped after the Brussels congress, only to reappear in the form of a discussion about mutual funds at the Berlin congress.

Other organizing countries also managed to insert specific national interests into the agenda. Vienna set great store by 'ethnographical' statistics, a branch of 
population statistics that suited the needs of the Habsburg Vielvölkerstaat particularly well. The director of the Habsburg statistical service, Karl von Czoernig, born in Bohemia and stationed in the imperial bureaucracy of Trieste and Milan between 1828 and 1841, believed strongly in the viability of a multi-national state. In 1857, the year that the international statistical congress was held in Vienna, he published the second part of his Ethnographie der österreichischen Monarchie, a eulogy of the Austrian reforms implemented after 1848. The book was accompanied by an unprecedentedly detailed map of the Austrian empire, based on the census of 1851. It showed all administrative units and all ethnic and language groups within the borders of the Habsburg Empire in different colours and was a work of art that had demanded the utmost of the printer. The purpose of the map, however, was not to show off the fine quality of Austrian printing, but rather to highlight the sheer impossibility and illusion of creating a state or states on the basis of nationalistic aspirations.

The London congress of 1860 was imbued with the spirit of the sanitary movement that had gradually taken possession of reform-minded Britain since the 1830s. At the congress, William Farr and Edwin Chadwick were the main spokesmen of the public health movement. The driving force, however, was Florence Nightingale, who - though she did not attend the sessions - played an influential role behind the scenes. She gathered the leading statisticians of different countries at her house in order to cement peace in Europe. ${ }^{25}$ She was deeply moved by her encounter with Quetelet, with whom she continued to correspond. A copy of Quetelet's Sur l'homme with numerous comments in the margins added by Nightingale shows the strong influence of the Belgian savant on his British friend. She presented a general scheme for hospital statistics to the congress, which the participants discussed, approved and praised.

In similar ways Germany put social insurance and 'social self-help' on the agenda, Italy came up with municipal statistics and wanted to keep count of arts and culture, the Netherlands paid particular attention to colonial statistics, Russia had particular wishes with regard to the census and Hungary promoted investigations into domestic industry. These special, sometimes patriotically inspired, topics were even harder to internationalize than the more recurrent themes of the statistical congresses. Participants either showed no real interest in these issues or denounced their political background.

\section{Transmission}

The second stage of the communication process is transmission. The traditional means of passing on knowledge across borders, tested and improved by artistic and intellectual elites over the centuries, were visits to masters of a certain art or science, study trips to other countries ('le grand tour'), universities and academies, and communication through international correspondents, letters, books and periodicals. Knowledge continued to travel in these ways, and at an increasing pace as the European railway network expanded. As late as 1890, a young Italian professor of 
statistics was still following the classic model. While a member of the Italian delegation to the international conference on the regulation of labour conditions held in Berlin, Giuseppe Majorana, recently installed at the University of Messina, presented himself to leading intellectuals in his field with introductory letters written by his father Salvatore Majorana Calatabiano, a former minister of agriculture, industry and trade. In Berlin, Majorana visited Gustav Schmoller and Adolph Wagner. Continuing his journey he went on to see Maurice Block, Gustave de Molinari, Frédéric Passy and Émile Levasseur in Paris. They exchanged books, scientific opinions and worldviews, in much the same way as their intellectual ancestors had done for centuries. ${ }^{26}$

The beginning of Quetelet's career is also a marvellous example of an 'enlightened' transnational apprenticeship. After completing his studies in his native Ghent, he continued his academic education in Paris with Laplace and Fourier. He visited many internationally renowned scholars, such as Schumacher and Olbers (both astronomers), Encke and Poggendorff (physicists), the composer Mendelssohn and of course Goethe in 1829. He started exchanging letters with many prominent savants, ${ }^{27}$ circulating his articles among well-known scholars, and co-founding, with Jean Guilaume Garnier, a scientific journal called Correspondance mathématique et physique which aimed to connect all practitioners of the quantitative sciences. He also used the journal to maintain a public correspondence with the French physician Louis Villermé about birth and mortality rates, and about the extent to which these rates were convertible to social laws.

Quetelet must have understood, however, that individual visits and scientific correspondence would not suffice to bring progress and uniformity in Europe in his lifetime. Following preliminary ideas developed by Condorcet, he started to devote his energies to trying to assemble scholars of different backgrounds and nationalities at scientific gatherings. ${ }^{28}$ Quetelet was surely not the first to experiment with this format, but by the mid-nineteenth century he had sufficient experience and status to act as 'first among equals' in different environments. Moreover, he was Belgian. In the decades after its secession from the Kingdom of the Netherlands, Belgium had become a centre of 'free trade' in technology and scientific knowledge. Though much smaller than Paris, Brussels competed with the French capital as a centre of academic excellence.

The relatively new format of knowledge transfer - the international scientific congress - would become hugely successful in the second half of the nineteenth century. The number of sessions increased from 26 in the 1850 s to 1351 in the first decade of the twentieth century. Initially, however, it was far from evident how an international scientific congress should be organized. The statistical congress, apart from being one of the first truly international congresses, had the additional problem that it encompassed the fields of both science and politics. As noted above, by the mid-nineteenth century most European states had a statistical office, usually attached to one of the government ministries. Quetelet and his co-organizers made sure that they had invited the officials who were in charge of those administrative 
bodies, although it remained unclear to what extent these officials actually enjoyed a special status at the congresses.

The organization of the congress itself was an item on each agenda of the consecutive gatherings. The thorniest issue was perhaps the choice of language. During the first two congresses, held in Brussels and Paris, the question went unanswered since the language of government in both host countries was French. But during the subsequent congresses, held in countries where French was at best the second language, the organizers insisted that participants be allowed to speak the first language of the host country, since the vast majority of participants invariably came from the organizing country. Hence, despite the general assumption of mastery of French among the elites, the accentuation of national languages at international gatherings was readily accepted. After another dispute about language at the last congress, held in Budapest in 1876, the Italian representative Cesare Correnti tried to settle the matter by addressing the audience in Latin. Frustra.

The followers of Quetelet strongly believed in the idea that numbers were selfevident, and laws would emerge automatically from systematically collected data. However, they had to acknowledge that in order to collect useful numbers it was necessary to achieve uniformity in the organization of statistics, starting with the way the congress itself was structured. The idea was that it would evolve from a loose gathering of savants taking non-binding decisions to an efficient and authoritative supranational agent of statistical research. The inner circle of official delegates, that is, the participants who were being paid by their governments to attend the congresses, tried to extricate itself from the congress, and began to organize separate gatherings. A formal 'pre-congress' of official delegates was introduced in the run up to the fifth congress in Berlin; at the eighth congress in St Petersburg in 1872, there was much discussion as to whether a 'post-congress' should be held as well. At the same congress the active Russian head of statistics, Petr Petrovich Semenov, tried hard to get a 'permanent commission' off the ground, an issue that had been raised at the Berlin congress in 1863. To some extent the arguments that were exchanged were comparable to the debates about European integration after the Second World War. Most officials were in favour of an international permanent commission for statistics, but discovered that it was exceptionally difficult to decide how many members the commission should have, who would get a seat on the commission, who would preside, how many meetings should be planned, how the agenda should be set, and so on. A permanent commission did meet on several occasions between 1873 and 1878, but in different compositions and with different agendas. It was probably Otto von Bismarck himself who eventually pulled the plug, forbidding Prussian statisticians from participating after 1878 , thereby ending the era of the international statistical congresses. ${ }^{29}$

As a channel of knowledge transfer, the international statistical conference was certainly a new phenomenon in the second half of the nineteenth century. However, as the example of the international statistical congress has shown, this format was by no means a guarantee that the broader goals of such gatherings would be attained. How to organize an effective congress continued to puzzle the scientific 
community. Moreover, the congress could easily become a forum for competition and national suspicion. Evidence from other congresses confirms this conclusion. The creation of an international coinage - a subject that had its own international congress but was also discussed during the statistical congresses - stirred a lot of enthusiasm in the 1860 s, but was abandoned in the 1870 s, when currency development became a top priority of nation-building. ${ }^{30}$ The international sanitary congresses on cholera, as Valeska Huber has effectively shown, 'were spaces where distinctions and boundaries between professional and national cultures were defined and European feelings of superiority were cultivated'. ${ }^{31}$

\section{Implementation}

The last stage of communication is the reception and implementation of the message. The difficulties of organizing efficient congresses paled into insignificance compared to the intricacies of effecting any real compliance in the national states. Though the official delegates to the international statistical congresses were reimbursed for their travel and subsistence costs, they left their home countries without a clear mandate. In addition, the congress possessed no recognized supranational powers. The only way it could show success was if its resolutions were voluntarily accepted and implemented by the delegates' countries of origin.

One of the first hopes of Quetelet and his associates was that the states of Europe would organize their official statistical inquiries in the same way. In 1841 Belgium had established a Central Commission for Statistics, a mixed body of government officials, medical and school inspectors, university professors and independent scholars sharing an interest in statistics. It was Quetelet's conviction that state-sponsored statistical investigations were best steered by a team of scientific and administrative experts. The congresses in Brussels and Paris had already passed resolutions calling for the establishment of a central commission in each country when the topic was addressed again in Berlin in 1863. Both Ernst Engel, the hyperactive head of the Prussian statistical bureau, and the constitutionalist Rudolph von Gneist were active supporters. The pre-congress of official delegates, however, could not reach agreement on this issue, partly because many German delegates insisted on speaking their native language, which intensely irritated participants from other countries. The issue was raised again during the congress. Von Gneist defended the idea of a central commission, emphasizing that thus far the congresses had been of an 'amphibious nature', combining free academic discussion with indirect government participation. In his view, this practice was not a handicap. Amphibians had their place in nature. ${ }^{32}$ Central commissions should be based on the same principle (academic discussion supplemented with administrative knowledge), if possible with some decision-making power. The congress eventually endorsed his point of view, voting in favour of establishing central commissions, but left unanswered the crucial question of how to realize this plan in the states of Europe. The issue was discussed again in The Hague in 1869. The exchange of opinions showed that there were marked contrasts between different 
state systems (at least in how they were perceived), stages of economic development and ideologies. Germany, through Engel, held that a central commission was not enough, and preferred a pool of statistical societies, uniting state and socioeconomic interests. Henry Lord Houghton of England, however, abhorred the idea of centralization, even if it was intended to serve no other purpose than science. In the end the congress accepted a watered-down resolution stating that both administrative and scientific interests should guide statistical inquires. Nothing was said about how this resolution should be implemented.

Similar outcomes are discernable in other topics of interest addressed by the congress. The census was the item that appeared most frequently on the agenda. Important aspects, such as the periodization of the counts, the content of the questions and the debate as to whether the actual or legal population should be counted, were discussed again and again. On the one hand, this debate suggests that there was no consensus on the topic during the congress era and that, more importantly, the uniformity that the congress sought remained a vain hope. On the other hand, the impact of the congresses did differ from state to state. Some official delegates used the congresses to back up their claims for resources vis-à-vis their governments, but this did not necessarily lead to the uniformization of national statistics. It was much more difficult to depart from a road taken (path dependence) than to introduce new institutions or procedures from scratch, although this is a theory that does not always hold, as the following short selection of cases shows.

Generally speaking, the larger European states were reluctant to adopt the resolutions of the congress. There was still very little convergence in the way the government statistics of France, Britain and Germany were organized in the course of the nineteenth century. ${ }^{33}$ The official delegates of the larger countries often lamented the lack of interest shown by their respective governments in the outcomes of the congress. William Farr was unable to convince successive governments that more coordination and centralization was needed if Britain wanted to keep up with other European states. Alfred Legoyt started his report about one of the international statistical congresses with undisguised criticism of the French and other governments, which failed to give statistics its rightful place among public services: 'Why keep silent about it? Statistics is unpopular'. ${ }^{34}$ When the congress convened in Berlin in 1863 Ernst Engel had to accept the Prussian government's decision to force kindred spirits, such as Rudolf Virchow, Salomon Neumann and Hermann Schulze-Delitsch, to resign from the organizing committee.

For the smaller states, the picture is less clear. The Hungarian state, for example, which came into existence in 1867, modelled many of its statistical investigations on the resolutions of the congress. The Netherlands was quite eager to follow the instructions of the congress, but soon abandoned this path. Von Baumhauer, the influential head of the statistical bureau, was unable to capitalize on his international standing in the national political context where many were allergic to centralizing tendencies. The Dutch did not have a central commission for statistics when the idea was first proposed by the congress. A commission was established in 1858 , to some extent in line with the congress resolutions, but it was abolished in 
1861 because it was considered too expensive, it did not have enough political support and its recommendations were frequently disregarded (not unlike the congress itself). ${ }^{35}$ In 1834, soon after gaining independence, Greece established a Bureau of Political Economy, inspired by the British (Board of Trade) and French examples. This bureau was also responsible for national statistical inquiries. In 1855 and from 1867 onwards the heads of the bureau proved to be attentive participants in the international statistical congresses. From 1861 onward, Greek censuses were organized on the basis of resolutions passed by the congress. ${ }^{36}$

In the sphere of public health and sanitary services the congress passed an impressive list of resolutions: in Paris in 1855 on traffic and industrial accidents, on epidemics, on causes of death and on madness; in Vienna in 1857 again on causes of death and epidemics, on sanitary institutions and personnel, on hydrophobia as a result of animal bites and on the influence of geographical conditions on health; in London in 1860 on hospitals, on military sanitation, on sanitary statistics in general ('plan to determine the sanitary conditions of the population of all civilized states') and on vital statistics on ships; in Berlin in 1863 on comparative statistics of the health of the civil and military population. Thereafter, interest in sanitary statistics declined, probably because the sanitary congresses were firmly established by then and general international medical congresses were launched in $1867 .{ }^{37}$ The medical topics that the statistical congress addressed were complex and tied up with deeprooted local traditions of dealing with public health issues. As much as some participants (the English delegate William Farr being among the first) wanted to arrive at a generally accepted nomenclature of causes of death and a uniform registration, this key issue in health statistics was difficult for the congress to solve. Although Farr's system became the template for further revisions of causes of death classifications, national resistance to international harmonization remained vigorous until well into the twentieth century. ${ }^{38}$

The deliberations usually ended in the same way: with an open resolution that left ample discretion to the governments addressed. Of course, in the nineteenth century (and perhaps even the twentieth) this was all Europe could hope for. It would be anachronistic to assume that while the instruments of national integration were being refined, effective international cooperation was likely to succeed. ${ }^{39}$

\section{Conclusion}

Starting from Kaelble's suggestion to disentangle the transnational world of connections and transfers, this paper has focused on the international statistical congresses held in the third quarter of the nineteenth century. These congresses were a significant step forward from the practice of 'learned consultation' (individual study visits and private correspondence) that characterized the Republic of Letters. This new form of knowledge transfer, however, did not develop smoothly. ${ }^{40}$ By scrutinizing the consecutive stages of statistical knowledge transfer via the congresses, I have singled out a series of critical moments, which impacted 
on attempts to converge national standards. Opening channels for transfer and exchange could have adverse or, at least, unwanted results (not to mention the transfer of false knowledge, which can also be regarded as a form of transfer). ${ }^{41}$ It could be argued that Quetelet's profound belief in social laws and universal quantification, which the congresses helped to spread, was a mixed blessing for the development of the science and practice of statistics: there were too many numbers and not enough direction.

The basic communication model I have used (highlighting the sources, transmission and reception of statistical knowledge) points to a range of other problems facing governments, the international statistical congress and individual actors at various stages in the transfer process. The congress movement itself, represented by a core group of frequent participants (mostly the official delegates), had great difficulty taking the congress beyond the original format, which became increasingly less effective. As a result, the congresses ended not with a bang but a whimper in the second half of the 1870s, when the Germans refused to participate in the permanent commission. Setting the agenda, choosing a language, organizing efficient deliberations, drawing up legitimate resolutions, eliminating national hang-ups and, last but not least, standardizing statistical inquiries continued to be vexed projects. Of course, this does not mean that the international statistical congress was entirely redundant. 'New' countries, such as Greece or Hungary, seeking to set up new statistical services, sent representatives to the congress, thereby securing immediate access to inside information about best practices in national statistics. Heads of national bureaus, by referring to the congress, were able to strengthen their position and acquire funds for specific investigations or organizational innovation. While still serving as head of statistics in Saxony, Ernst Engel used the congress deliberations creatively to organize the state census of 1855 in accordance with his ideas about efficiency, in particular by making use of forms which heads of households and producers had to fill in themselves - a method that had not yet been widely employed in Europe and which the congress had not dared to impose on European governments.

It would be too narrow, however, to look only at institutions, regulations and procedures that developed in European states as a direct result of the congress. Granted, the congress was an important phase in the acceptance of statistics as a guiding instrument of political decision-making. By the end of the nineteenth century it was impossible to imagine modern government functioning without statistics. As the French historical sociologist Brian observed, the congresses helped to build an intellectual capital that formed the basis of the subsequent transnational authority of statistics. ${ }^{42}$ The long-term indirect and unintended consequences of the congresses were perhaps more significant than the express wishes of the protagonists: the creation of the International Statistical Institute in 1885, the growth of national statistical bureaus, the use of efficient methods (e.g. the graphical method), the spread of ideas on social reform, and last but not least, the intensification of nation-building processes throughout Europe. 


\section{Notes}

1. The sole exception was the 1869 conference held in The Hague, which is the seat of government but not the capital of the Netherlands. A first draft of this article was presented at the 2007 bi-annual Anglo-Dutch-German workshop organized by the Wellcome Trust Centre for the History of Medicine at UCL, 21-23 June 2007.

2. E. Brian, 'Transactions statistiques au xixe siècle. Mouvements internationaux de capitaux symboliques', Actes de la recherche en sciences sociales, no. 145 (2002/5), 34-46.

3. F. S. Lyons, Internationalism in Europe 1815-1914 (Leiden 1963); M. Geyer and J. Paulmann, eds, The Mechanics of Internationalism: Culture, Society, and Politics from the 1840s to the First World War (Oxford 2001).

4. See, among many other examples, the review by Achille Guillard of Johann Eduard Wappäus, Allgemeine Bevölkerungsstatistik in 'Démographie (lois de population)', Journal de la Société de Statistique de Paris, Vol. 2 (1861), 277-88.

5. For example, the 'border crossing potential' of social policy and the analysis thereof were recently proposed by M. Herren, 'Sozialpolitik und die Historisierung des Transnationalen', Geschichte und Gesellschaft, Vol. 32 (2006), 542-59.

6. J. Paulmann, 'Internationaler Vergleich und interkultureller Transfer. Zwei Forschungsansätze zur europäischen Geschichte des 18. bis 20', Historische Zeitschrift, Vol. 267 (1998), 649-85.

7. M. Espagne, 'Sur les limites du comparatisme en histoire culturelle', Genèses no. 17 (1994), 112-21; M. Espagne, ed., Les transferts culturels franco-allemands (Paris 1999).

8. R. W. Strayer, ed., The Making of the Modern World: Connected Histories, Divergent Paths, 1500 to the Present (New York 1989); L. A. Tilly, 'Connections', American Historical Review, Vol. 99 (1994), 1-17; J. Osterhammel, Geschichtswissenschaft jenseits des Nationalstaats. Studien zu Beziehungsgeschichte und Zivilisationsvergleich (Göttingen 2001); S. Conrad and S. Randeria, eds, Jenseits des Eurozentrismus. Postkoloniale Perspektiven in den Geschichts- und Kulturwissenschaften (Frankfurt a/M 2002); P-Y. Saunier, 'Circulations, connexions et espaces transnationaux', Genèses, Vol. 4, no. 57 (2004), 110-26.

9. M. Werner and B. Zimmermann, eds, De la comparaison à l'histoire croisée (Paris 2004); M. Werner and B. Zimmermann, 'Beyond Comparison: Histoire Croisée and the Challenge of Reflexivity', History and Theory, Vol. 45 (2006), 30-50.

10. D. Sassoon, One Hundred Years of Socialism: The West European Left in the Twentieth Century (London 1996).

11. P-Y. Saunier, 'Taking Up the Bet on Connections: A Municipal Contribution', Contemporary European History, Vol. 11 (2002), 507-27, and following articles in this issue; P-Y. Saunier, 'Les régimes circulatoires du domaine social 1800-1940: projets et ingénierie de la convergence et de la différence', Genèses, Vol. 2, no. 71 (2008), 4-25.

12. N. Randeraad, ed., Formation und Transfer städtischen Verwaltungswissens. Jahrbuch für Europäische Verwaltungsgeschichte 15 (Baden-Baden 2003).

13. W. Kaiser, 'Cultural Transfer of Free Trade at the World Exhibitions, 1851-1862', The Journal of Modern History, Vol. 77 (2005), 563-90.

14. H. Kaelble, 'Die Debatte über Vergleich und Transfer und was jetzt?', URL (consulted 17 May 2007): http://geschichte-transnational.clio-online.net/forum/2005-02-002

15. Part of what follows is the subject of my recent book on statistics in nineteenth-century Europe, N. Randeraad, States and Statistics in the Nineteenth Century. Europe by Numbers (Manchester 2010). 
16. S. J. Woolf, 'Statistics and the Modern State', Comparative Studies in Society and History, Vol. 31 (1989), 588-604.

17. A. Rasmussen, 'Jalons pour une histoire des congrès internationaux au XIX ${ }^{\mathrm{e}}$ siècle: Régulation scientifique et propagande intellectuelle', Rélations internationales, no. 62 (1990), 115-33, in particular 122.

18. See for example on the Italian congresses U. Levra, 'Gli uomini e la cultura delle riforme', Atti del LVI congresso di storia del Risorgimento italiano (Roma 1994), 129-68; and M. P. Casalena, 'The Congresses of Italian Scientists between Europe and the Risorgimento (1839-75)', Journal of Modern Italian Studies, Vol. 12 (2007), 153-88.

19. Compte rendu des travaux du congrès général de statistique réuni à Bruxelles les 19, 20, 21 et 22 septembre 1853 (Bruxelles 1853), 23.

20. V. Huber, 'The Unification of the Globe by Disease? The International Sanitary Conferences on Cholera, 1851-1894', The Historical Journal, Vol. 49 (2006), 453-76.

21. T. Porter, The Rise of Statistical Thinking: 1820-1900 (Princeton 1986).

22. Congrès International de Statistique à la Haye, Compte-rendu des travaux de la septième session. Seconde Partie (The Hague 1870), 38-9.

23. C. Leonards, De ontdekking van het onschuldige criminele kind. Bestraffing en opvoeding van criminele kinderen in jeugdgevangenis en opvoedingsgesticht, 1833-1886 (Hilversum 1995), 183.

24. A. Rasmussen, op. cit., 119.

25. M. Vicinius and B. Niergaard, eds, Ever Yours, Florence Nightingale. Selected Letters (London 1989), 208.

26. G. Majorana, Le Grand Tour. Lettere alla famiglia 1890 (Palermo 2000).

27. See L. Wellens-De Donder, Inventaire de la correspondance d'Adolphe Quetelet déposée à l'Académie royale de Belgique (Bruxelles 1966).

28. E. Brian, 'Y a-t-il un objet "Congrès"? Le cas du Congrès international de statistique (1853-1876)' Mil Neuf Cent. Revue d'histoire intellectuelle, Vol. 7 (1989), 15.

29. J. W. Nixon, A History of the International Statistical Institute 1885-1960 (The Hague 1960), 9.

30. M. H. Geyer, 'One Language for the World: The Metric System, International Coinage, Gold Standard, and the Rise of Internationalism, 1850-1900', in Geyer and Paulmann, eds, op. cit., 55-92.

31. Huber, op. cit., 470.

32. Die fünfte Sitzungsperiode des internationalen statistischen Congresses in Berlin vom 4. bis 12. September 1863, II, 97.

33. A. Desrosières, La politique des grands nombres. Histoire de la raison statistique (Paris 1993).

34. A. Legoyt, 'Les congrès de statistique et particulièrment le congrès de statistique de Berlin', Journal de la Société de Statistique de Paris, Vol. 4 (1863), 271.

35. I. H. Stamhuis, 'Cijfers en Aequaties' en 'Kennis der Staatskrachten'. Statistiek in Nederland in de negentiende eeuw (Amsterdam 1989), 207-11.

36. K. Chatzis, “'Sous les yeux de l'Occident”. Statistiques et intégration européenne au $\mathrm{XIX}^{\mathrm{e}}$ siècles, l'exemple de la Grèce', Revue Européenne d'Histoire Sociale, no. 21 (2007), $8-17$.

37. V. Huber, op. cit.; W. F. Bynum, 'Policing Hearts of Darkness: Aspects of the International Sanitary Conferences', History and Philosophy of the Life Sciences, Vol. 15 (1993), 421-34. 
38. G. C. Alter and A. G. Carmichael, 'Classifying the Dead: Toward a History of the Registration of Causes of Death', Journal of the History of Medicine and Allied Sciences, Vol. 54 (1999), 114-32, and other articles in this volume; F. van Poppel and J. P. van Dijk, 'The Development of Cause-of-Death Registration in the Netherlands, 1865-1955', Continuity and Change, Vol. 12 (1997), 265-87.

39. It has been suggested that the nineteenth-century knowledge network can be compared with today's 'epistemic communities', networks of 'professionals with recognized expertise and competence in a particular domain and an authoritative claim to policy-relevant knowledge within that domain or issue-area' (P. M. Haas, 'Introduction: Epistemic Communities and International Policy Coordination', in P. M. Haas, ed., Knowledge, Power, and International Policy Coordination [Colombia, SC, 1992], 3). Part of the literature in this field is concerned with the question as to under what conditions epistemic communities can exert influence. Clearly, in this perspective the nineteenth century was hardly a fertile breeding ground for mobilizing networks of scientific expertise. See S. Kott, "Une "communauté épistémique" du social? Experts de l'OIT et internationalisation des politiques sociales dans l'entre-deux-guerres', Genèses, Vol. 2, no. 71 (June 2008), 26-46; C. Leonards and N. Randeraad, 'Transnational Experts in Social Reform, 1840-1880', International Review of Social History, Vol. 55 (2010), 215-39.

40. Independently, and following a different line of reasoning, Lawrence Goldman came to similar conclusions, see his unpublished paper on the International Statistical Congress delivered to the 'Social Policy Across Borders' conference, Cambridge 12-13 September 2008 .

41. There were, for example, two conflicting theories on the origins of cholera, which were both being propagated and spread through international congresses. Did the 'right' theory emerge more rapidly as a result of the increase in communication, or was its acceptance postponed?

42. E. Brian, 'Transactions statistiques au xixe siècle', 46.

Nico Randeraad is lecturer in history and European Studies in the Faculty of Arts and Social Sciences, Universiteit Maastricht. He studied history at the Free University Amsterdam and at the European University Institute. $\mathrm{He}$ is the author of States and Statistics in the Nineteenth Century: Europe by Numbers (Manchester 2010) and editor (with H. Jones and K. Östberg) of Contemporary History on Trial: Europe since 1989 and the Role of the Expert Historian (Manchester 2007). 